Department of Business Administration

UZH Business Working Paper Series

Working Paper No. 310

Thinking Inside the Box: Linking Dynamic Capabilities to

Theories of Action

Donald MacLean, Robert MacIntosh, David Seidl

13 August 2012

University of Zurich, Plattenstrasse 14, CH-8053 Zurich, http://www.business.uzh.ch/forschung/wps.html 
UZH Business Working Paper Series

\section{Contact Details}

\section{Donald MacLean}

University of Glasgow

Gilbert Scott Building

GB-Glasgow G12 8SQ

Email: Donald.MacLean@glasgow.ac.uk

Telephone: 01413304649

\section{Robert MacIntosh}

University of Glasgow

Gilbert Scott Building

GB-Glasgow G12 8SQ

Email: Robert.MacIntosh@glasgow.ac.uk

Telephone: 01413304938

\section{David Seidl}

University of Zurich

Universitätsstrasse 84

$\mathrm{CH}-8006$ Zurich

Email: david.seidl@uzh.ch

Telephone: +41 446343750 


\title{
THINKING INSIDE THE BOX: LINKING DYNAMIC CAPABILITIES TO THEORIES OF ACTION
}

\begin{abstract}
We argue that development of dynamic capabilities theory into a fully dynamic theory of strategy is inhibited by the operation of an incomplete set of perspectives on human action. Clarifying how human action is conceptualized, particularly as regards creativity and learning, might help strategy scholars to develop theory in ways that adequately address action at all levels of engagement in dynamic contexts, thereby turning existing contradictions into complementarities whilst accounting for issues of both content and process. By reorganizing existing literatures along action theoretic lines the paper reframes some of the difficulties in current theorizing, illustrates the value of this reframing by applying action theory to recent work on dynamic capabilities and proposes a rules-based framework as a potential integrating device for the field. The paper closes by highlighting the need for interdisciplinary research in strategy.
\end{abstract}

\section{KEYWORDS}

Dynamic capabilities, action theory, creative action, learning, rules 


\section{INTRODUCTION}

In a recent "coming of age” paper on the Resource-Based Theory (RBT), Jay Barney and colleagues reflect on the evolution and possible future of the field after twenty years of sustained effort (Barney et al. 2011). They end the paper by concluding that scholars must help RBT “innovate or die” (Barney et al. 2011: 14) and they cite Foss (2011) to highlight the fact that theoretical development is limited by having "no unified model of people, but rather, different models ranging from the hyper-rational model of people offered by game theory to the stimulus-response puppets of some versions of behaviorism” (op. cit.: 10). RBT has made important progress in taking us inside the "black box" (Pavlou and el Sawy 2011) and renewed promise may lie in clarifying the role and nature of human action in organizational strategy processes.

The concerns for RBT are salient across the rapidly growing literature on dynamic capabilities (DC), which spans theoretical works, (e.g., Teece et al. 1997; Eisenhardt and Martin 2000; Helfat 2000; Helfat and Peteraf 2003; Teece 2007; Helfat et al. 2007), empirical research (e.g., Danneels 2010) as well as reviews and critiques (e.g., Makadok 2001; Winter 2003; Zahra et al. 2006; Wang and Ahmed 2007; Ambosini and Bowman 2009; EasterbySmith et al. 2009; Barreto 2010; Di Stefano et al. 2010). Leading scholars have called for greater attention to be paid to the role of managers through a behavioral theory of the firm (Cyert and March 1963, Augier and Teece 2007) or through studies of “dynamic managerial capability” (Adner and Helfat 2003, Helfat et al. 2007, Martin 2011), namely “the capacity of managers to create, extend or modify the resource base of an organization” (Helfat et al. 2007: 121) through management processes such as asset orchestration (Sirmon and Hitt 2009) that lead to evolutionary and technical fitness (Helfat et al. 2007).

DC scholars have done much to counter early critiques that the concept is "tautological" (Williamson 1999), internally inconsistent (Zahra et al. 2006) and thus empirically untestable 
(Kratz and Zajac 2001). Indeed, it is argued that although calls for further development persist DC is in its infancy relative to other fields (Helfat and Peteraf 2009). Responses have centered on behavioral theory, cognition, and the everyday activities of managers (Gavetti 2005; Gavetti and Rivkin 2007; Oliver and Holzinger 2008; Oliver and Holzinger 2008; Regnér 2008; Augier and Teece 2009; Laamanen and Wallin 2009; Salvato 2009; Eisnhardt et al. 2010; Barney et al. 2011; Foss 2011) which fall broadly within the decision-making subfield of strategy process (March 1994). Whilst this is a vital area, we take the position that it is necessary but not sufficient in and of itself. A focus on decision-making does not adequately deal with the multifaceted nature of human action; indeed the former can be seen as an outcome of a rich set of interacting emotional, social, and historical embodied processes. We need to know more about the complex dynamic in which decisions are reached if we are to develop a theory of dynamic capabilities which resonates with the fullness of everyday management experience. In short, we need to conceptualize strategists as well as strategic decisions.

Our use of theories of action falls within the scope of what Helfat and colleagues have termed Dynamic Managerial Capabilities (Adner and Helfat 2003; Helfat et al. 2007) and is distinct from, though complementary to ongoing work concerned with decision-making. We argue that to successfully account for the "how" of managerial action as opposed to the "what" of managerial decisions, DC scholars need to review the inadvertent tendency toward a theoretical fundamentalism which largely favors rationalism.

By reorganizing existing literatures along the lines of different concepts of action and by introducing a novel theory of action, we aim to “work on the complementarities among the existing theoretical approaches to form a more integrated conceptualization of the firm,” recognizing that "novel theoretical lenses can potentially add significant value to the current state of the art” (Peteraf et al. 2008: 1111). This requires the addition of a theoretical means 
of accounting for the action of the embodied strategist - alongside accounts of disembodied strategic decisions and unified behavior of the firm. The central argument of this paper is thus that a fuller explanation of the strategist - i.e., those enacting dynamic managerial capabilities - requires the incorporation of a creative action lens alongside more traditional perspectives on human action. To make this argument we examine the axiomatic core of DC thinking as regards human action, and suggest a means of developing a view of DCs that integrates both decisions and action as key dimensions of content and process respectively.

\section{ACTION IN DYNAMIC CAPABILITIES}

The two most heavily cited DC papers offer a useful means of examining tensions in the literature (Di Stefano and Peteraf 2011). In the words of Teece et al. (1997), dynamic capabilities are path-dependent combinations of processes, positions and paths through which firms engage in a Schumpeterian climate of creative destruction (Schumpeter 1943) under the stewardship of rational managers. Processes are "the way things are done in the firm, or what might be referred to as its routines or current patterns of learning” (Teece et al. 1997: 518). While they work with a view of managers as rational (op. cit.: 527, Table 1), the authors' frustration about the limits of rationalism is also visible since they note that "an organization cannot improve what it cannot understand," adding that "knowledge is highly tacit" (op cit: 525 and "perhaps even more important than integration is learning". Yet learning is acknowledged as an intrinsically social creative practice. Rather than seeing learning as the accumulation of experience, as it is typically framed in evolutionary economics (Nelson and Winter, 1982), we believe that there is a need to deepen our understanding of learning as an intentional, primary process rather than a social byproduct.

The other heavily cited DC paper (Eisenhardt and Martin 2000) details the finer-grained nature of DC and refutes criticisms of tautology and vagueness (Williamson 1999; Priem and Butler 2001a and 2001b). Eisenhardt and Martin also describe DC as comprising key 
"processes that integrate, reconfigure, gain and release resources" (2000: 1107), before homing in on routines as the basic component of DCs - "dynamic capabilities are thus organizational and strategic routines by which firms achieve new resource configurations as markets emerge, collide, split, evolve and die” (op. cit.: 1107). Again, there is an implicit view of firms and managers as rational, but this rationality is grounded in an evolutionary perspective of historically constrained emergence, combination and recombination. As they write, DCs are “complicated routines that emerge from path-dependent processes” (op. cit.: 1114) and are often expressed as simple rules in high velocity markets in which market dynamism demands "the creation of new situation specific knowledge” (op. cit.: 1112). As in the earlier work of Teece et al., the mysteries of emergence in such specific situations are linked with learning processes the details of which are not elaborated.

These two papers have helped advance RBT in general and DC in particular (see Barney et al. 2011 and Barreto 2010 respectively for the latest comprehensive overviews), yet also highlight implicit assumptions which, we argue, are constraining development. Overall, it appears that DC theory is acknowledged as a powerful means of explaining the benefits accruing to firms, especially when firms are treated as a rational black box pursuing optimization. However, any move "inside” the box brings the realization that the operation of such capabilities rests on routines, rules, values, etc. These relate to the performance of a collective and emergent historically structured pattern in which rationality itself is located. Finally, and in tune with the familiar action-structure debate in social theory (Thietart and Forgues 1997; Baert 1998), the DC approach also leaves us wondering about the role of individual human action in the genesis, creation of, response to and maintenance of such structures. While the creativity of and the constraints on the individual strategist are acknowledged, they are barely explored. 
The idea of dynamic managerial capability (Helfat et al. 2007) points to the central role of managers and strategic actors in creating and modifying resources, as they sense and seize opportunities in rapidly shifting environments. Ongoing work is developing our understanding of the role of individual discretion in managerial decisions (Finklestein and Peteraf 2007). Yet, a fuller understanding of the myriad of factors in decision-making requires a theory of human action geared towards explaining the dynamics of creative, situationspecific learning processes both in and as social practice. As yet, there appears to be no agreed way of incorporating such detail into the theoretical apparatus (Tsoukas and Knudsen 2003). What, for example, about everyday phenomena such as emotion, intuition and imagination; or politics, leadership and private agendas; or identity, the negotiation of meaning and chance? (Mitroff and Lyles 1984; Allison 1998) This lack of purchase on everyday reality perhaps explains the fairly weak pointers to "learning” and the ongoing calls for a microfoundation. It is clear that instead of focusing more closely on how to tackle this difficulty, the conceptual lens tends to zoom out and away from detail, presenting arguably vaguer, aggregative ideas such as innovation, change and learning (Teece 2007).

\section{RATIONAL AND NORMATIVE CONCEPTS OF ACTION IN STRATEGY}

We argue that there is an unacknowledged bias in the strategy literature with regard to human action and that DC thinking needs to reflect on its own foundations in rational and normative conceptions of human action. Much of western scientific thought is founded on rational approaches, characterized by the explicit analysis of ends, means and conditions in pursuit of some optimum. Normative views of action are primarily concerned with the development and persistence of social, cultural and historical patterns in collectives and with members' shared cognitive and social structures, values and norms (Joas 1996). Here we use "rational" as shorthand for what Weber termed "instrumentally rational” (zweckrational) i.e., based on calculation as opposed to "value rational” (wertrational), traditional (habitual) or affective 
(emotional) forms of social action (Weber 1978). Hence the term "rational” here connotes formal economic rationality, where behavior is viewed as instrumental in the pursuit of utility (Hendry 2002) or, in the case of firms, profit maximization. In evidencing the influence of rational approaches we would cite a steady stream of relatively user-friendly, quasieconomics frameworks produced by academics such as strategy-structure-performance (Chandler 1962; Rumelt 1984), structure-conduct-performance (Bain 1956), corporate and business environment (e.g., Andrews 1971; Porter 1980, 1985) through the resource base (Wernerfelt 1984; Rumelt 1984; Prahalad and Hamel 1990; Barney 1991) and, of particular relevance to this paper, dynamic capabilities (Teece et al. 1997; Helfat 2000; Eisenhardt \& Martin 2000). Normative conceptions of action are evident in concepts such as "dominant logics” (Bettis and Prahalad 1995), shared strategic intent (Hamel and Prahalad 1989), paradigm (Johnson 1988) industry recipes (Spender 1989). They can even be discerned in RBT through acknowledgement of organisational repertoires of embedded competences (Prahalad and Hamel 1990; Bogner et al. 1999) and routines (Nelson and Winter 1982; Miner 1994).

To some extent, rational and normative views are sides of the same Cartesian coin. In the former, action is intellectually driven; in the latter, intellect expresses the deep values and norms underpinning actions which are socially structured. One foregrounds premeditated mechanical action; the other focuses on persistence and patterning in social form. Neither explains the inherent dynamics of spontaneous creativity in which bodily action and intellectual activity are dialogically intertwined. Joas claims that the relative neglect of creativity in the social sciences limits our ability to deal with the challenges of contemporary society (1996). In turn, we argue that the axiomatic core of strategy is struggling to keep up with broader changes in society. 
In relation to DCs, we now perceive a new problem - or perhaps an old problem in a new light: the DC literature appears to straddle the two main conceptions of human action by conceiving the firm as a rational actor while using the normative routines and rules as the way in which DCs are expressed. If accepted, this introduces theorizing difficulties that are not explicitly acknowledged (Tsoukas and Knudsen 2003). DCs offer a theory of change as a rational problem-response or normative triggered-outcome, both of which are devoid of detailed explanations of the action through which change actually occurs. This theoretical hollowing out offers a major opportunity if a novel lens (Peteraf et al. 2008) primarily concerned with explanations of enacted creativity can be incorporated into DC research. Any new lens would complement existing views of control, problem-solving and sustainability and might provide a robust DC micro-foundation which clearly accounts for management action.

\section{CREATIVE ACTION}

In acknowledging the messiness and complexity of strategic behavior, a growing body of work highlights the importance of context in influencing strategy. Here strategic behavior is inextricably bound up in context with emphasis given to chance, ignorance, private agendas, and, most importantly, individual personalities. This acknowledgment of the non-corporate, private, emotional, intuitive individual, and indeed the recognition of the organization as a melting pot of numerous personal biographies and power relations (Allison 1998), is at odds with both the rationalist conception of the monolithic decision-maker and the normative view of a triggered herd reaction.

Despite a high degree of diversity both in the theoretical terms used and the timing of their appearance in the literature, researchers in this group are united by their openly critical stance toward (a) traditional Cartesian rationalism in which the sequencing of thinking and action divides content and process and (b) normative views that persistence rather than change is the fundamental feature of social patterns (Joas 1996). Moreover, the main concern is with the 
outcomes of context-specific, quasi-political practices and processes in organizations (Pettigrew 1973, Allison 1998) which tend to cast strategic behavior as- at least partly- an emergent phenomenon (Mintzberg 1978).

Work in this vein, attempting to explore strategy and organizational change, includes the emergent fields of chaos theory (Thietart and Forgues 1997), complexity theory (MacIntosh and MacLean 1999), theory of distributed knowledge (Tsoukas 1996), structuration theory (Whittington 1992) and certain forms of institutional theory (Mayer and Whittington 1999), amongst others. The common thread is a focus on strategic behavior as an emergent outcome amongst co-evolving and interacting players. The concern with micro-phenomena, embeddedness (Granovetter 1984) and context as "situatedness” is variously expressed as a degree of sympathy with "the practice turn” in social theory (Whittington 2006), a focus on knowledge (Spender and Grant 1996), knowing, action and learning in communities of practice (Wenger 1998) or in ideas such as strategy as practice (Johnson et al. 2007).

Both prominent social theorists (e.g. Joas 1996) and leading scholars of organization theory (e.g., Tsoukas and Knudsen 2003) have argued for a new theory of human action in which creativity is regarded as the primary facet of human action. Joas in particular sharply criticises rationally and normatively oriented concepts of action, and offers a theory of creative action based on a combination of insights from the traditions of American Pragmatism and German philosophical anthropology. In so doing, he questions the validity of approaches which assume a teleological view of intentionality, instrumental control of the body and autonomy of the individual.

Joas espouses a view in which intention is seen as a continually emerging facet of an ongoing dialogue between means, ends and context. Further, the body is seen a the source of personal expression, though not necessarily an instrument of the intellect, and identity is viewed as an evolving process occurring in social interactions: 
"only by introducing a concept of action which consistently takes account of this creative dimension can the other [i.e. rational and normative] models of action be assigned their proper logical place. As a consequence, only in such a manner can the wealth of concepts involved in the concept of action, such as intention, norm, identity, role, definition of the situation, institution, routine etc. be defined consistently and in a manner which does justice to what they are meant to express" (p5)

Perhaps the contrast between rational and normative views, on the one hand, and the creative view of action, on the other hand, is most expediently exemplified by referring to a familiar analogical situation such as team sports, where the creative urges of individuals are expressed as emergent outcomes which unfold as the game progresses. Dialogue between the means, end and situation reflects the continual co-evolution of aspirations, moves and tactics as the game ebbs and flows. No individual enters the match with a script or a set of triggered responses, though elements of both (in the form of plans, tried and tested formations, rehearsed set-piece routines, etc.) may come into play at appropriate moments. Indeed structures, routines and plans are central to a team's ability to improvise. What moves from potential to actual, from abstract to concrete is influenced by the embodied capabilities and urges of those who are playing the game. Skilful players move from one mutually created situation to the next; intention emerges in the moment - varying from winning the match, scoring a goal, stopping an opponent, seeking support, etc. Pain and injury matter. Health, mood, physicality and disposition count. Good players are not necessarily instrumentalizing their bodies as plans are executed. Sometimes the body takes over and the mind is witness to unpremeditated expression. More commonly, what is expressed and what intended are inextricably bound up in a way that defies traditional sequences of thought and action. Critically, interaction is central, since some relationships are productive and some are not. 
Everything that happens, happens through processes of inter-relating as players and teams experiment, learn, win, lose and build identities together.

Overall, this view of creative action departs from the fundamentally Cartesian orientation of its rational and normative counterparts in that the sequential separation of experience into thinking components and acting components doesn’t hold. We should also note that the three themes are mutually constitutive of each other, i.e., intention emerges through the physical body in social interaction, social interaction is influenced by embodied processes and intention, and biography develops along with emergent intention through social interaction.

\section{CREATIVE ACTION AS A TOOL FOR UNDERSTANDING DYNAMIC MANAGERIAL CAPABILITIES}

We have reviewed three perspectives which attempt to explain action, and our view is that such explanations are always partial. Indeed our understanding is made deeper and richer by holding and working with the different explanations and insights presented by these perspectives. Hence, our contribution is to show how viewing DCs in terms of creative action may deepen our understanding of what is acknowledged as an important topic (Helfat and Peteraf 2009) by focusing attention on issues which are neglected by existing perspectives.

Table 1 illustrates that it is possible to identify three different theories of action used explicitly or implicitly - in theorizing about DCs.

Insert Table 1 about here

If this mapping suggests a gap in our theorizing, what would a creative action perspective on DCs add to our understanding? To answer this question we return to the two seminal papers discussed earlier - Teece et al. (1997) and Eisenhardt and Martin (2000). In Teece et al., the 
firm as a set of DCs is cast as a rational, problem-solving actor seeking to maximize competitive advantage, implying that this is a systematic, quasi-scientific process in which ends, means and conditions are matched. This also conforms to Barreto's (2010) definition of DC. However, since DCs in turn comprise routines and rules, the emphasis switches from optimization and problem-solving to sustainability and co-ordination. This appears consistent with the development of the theories put forward both by Teece and his colleagues and by Eisenhardt and Martin. However, we suggest that the differences between these two authorteams are symptomatic of a (implicit) movement across levels of analysis and theories of action. Contrary to the view of Teece and his colleagues, Eisenhardt and Martin conclude that competitive advantage is neither optimized nor sustainable through the operation of DC, but that inclusion in an industry group is sustained by common routines. It almost slips past unnoticed that Eisenhardt and Martin have shifted their focus to issues of membership in a social structure and are therefore placing greater emphasis on normative theories. Teece and his colleagues, on the other hand, emphasize the link between dynamic capability and superior performance, explicitly stating that the dominant orientation of the firm is rational. Although each paper is consistent in its position, the two positions operate at different levels of analysis: the firm, on one hand, and, straddling this, the routine-strategic group on the other. Critically, neither deals in detail with the finer-grained processes or micro-foundations. We argue that this is because the concepts of action which they employ are geared towards other concerns.

Table 1 shows that a creative action lens focuses explicitly on the blind spots of rational and normative views, e.g, individual and group acts of spontaneous creativity and social learning in processes of human interaction. Creative action is much better equipped to explain the emergence of novelty through relational processes in which identity is constructed as highly contextual, emergent and embodied. Action is first and foremost embedded in everyday 
situations populated by individual human actors doing strategy (and other things) together. Bringing the strategist back into view would help furnish a fuller explanation of the operation of DCs. In practical terms we would need to add considerably more detail on (1) the biographies, aspirations, expressions and more private thoughts of the key actors in any situation, (2) the dynamics of their interactions and how such interactions related to processes of identity and meaning in the situation, and (3) how both (1) and (2) are influenced by and influence evolving processes of intention and action.

Consequently, to build a creative action perspective in DC research more work is needed in these three dimensions. Interestingly, one might regard this as traditionally more the domain of strategy process than content, but in fact these issues straddle both. We conclude by outlining a research agenda that deepens our understanding of these three areas and makes some observations about the implications for both method and the persistently problematic distinction between content and process.

\section{A RESEARCH AGENDA FOR DYNAMIC MANAGERIAL CAPABILITIES AS STRATEGIC ACTION}

To enrich our conceptualization of human action in DCs, we propose work in the following areas.

\section{Rationality, Intention and Emergence}

It is important to note that we are not saying that people, groups and firms are irrational, but simply that our conception of rationality and its treatment at different levels of analysis has to be more sophisticated. While it may be entirely appropriate, - at one level- to treat the firm as a unified rational actor seeking to solve problems, we would also argue that at the level of routines action is more concerned with the preservation of structures, social belonging and the cultural persistence of a collective or group. Moving one level down, whilst individual 
strategists may well be acting in accordance with clearly held intentions and goals, creative action would view these as being in continual evolution in what is largely a political dynamic. At the level of individual actors, interest would shift towards the quasi-improvised sense-andrespond movements through which emergent intentions, enacted practices and outcomes coevolve in order to achieve a workable marriage of selected individual, group and firm level aspirations and capabilities in any given situation.

\section{Firms, routines, strategists and embodied expression}

To a great extent, the evolution of intention described above is influenced not only by the specifics of any given situation, but also by the "baggage" of those involved. The acting human body is a subject of growing interest in organization theory but, at best, takes on various shadow-like appearances (Hassard et. al, 2000), primarily as an entity which is instrumentally manipulated in the service of the intellect. The body in all its fullness - as the location of experience and creative expression, the site of sensitivity, emotion, intuition, health, biography and aesthetic awareness- remains as marginalized as the biographies of the unique individual to which it relates (Beech and Johnson 2005). Allison argues forcefully that

"players are also people. Men's metabolisms differ. The core of the bureaucratic politics mix is personality. How each man manages to stand the heat in his kitchen, each player's basic operating style, and the complementarity or contradiction among personalities and styles in the inner circles are irreducible pieces of the policy blend. Moreover, each person comes to his position with baggage in tow, including sensitivities to certain issues, commitment to various programs, and personal standing and debts with groups in society" (Allison, $1998: 199)$ 
We therefore suggest that DC research needs to delve deeper into the influence of leadership, experience, relationships, personality, management styles, moods, intuition, poetics and inspiration. Detailed data on the behavior of the strategist(s) may of course be refined by selection structures and processes such as rules, routines, power structures and firm-level priorities, but as the creative substrate of variety-production, greater consideration of the embodied human personality is vital to our understanding of how DCs originate, operate and evolve.

\section{Strategy as problem-solving, sustainability, meaning and identity formation}

Our earlier analysis of two prominent DC papers established that existing DC research focuses on the optimization of firm-level competitive advantage and the sustained industry position. Whilst these are clearly key dimensions of strategy, we would argue that we need to deepen our understanding of the relationship between the ways in which strategies work for firms and what this means for the strategists who enact them. Research needs to strengthen our purchase on how the inter-subjective and functional dimensions of strategy are related, i.e., the question "How does strategy work?" needs to be better linked to "What does strategy mean?” for those involved. Creative action points to identity formation as fundamental to strategy as a social process. This has already been noted by some strategy scholars (Peteraf et al. 2008; Beech and Johnson 2005). Understanding the relationship between how strategy becomes effective, what "effectiveness" means to those involved and, critically, how involvement in (or exclusion from) the dialogic relation between the two may help cast new light on familiar issues of “implementation failure” (Pettigrew 1992).

\section{Implications for research designs and method}

Finally, it is worth noting that an enhanced set of lenses with which to view strategic action, in turn requires a broadening or rebalancing of the methodological repertoire. A move from 
the firm as black box to individual action implies granularity and subjectivity, which we suggest will necessitate the inclusion of phenomenological forms of research. Moving inside the box to research DCs from a creative action perspective is also likely to mean a more inductive form of theory building. One would therefore expect to see greater use of (and openness to) mixed methodologies and, in particular, an increasing role played by ethnographic studies, single or multiple case-studies, engaged “mode-2” (MacLean et al 2002) style projects and the like. In short, we need to get closer to the action.

\begin{tabular}{|c|c|c|c|}
\hline Level of analysis & Firm & Routine & Strategist \\
\hline Key Model of action & Rational & Normative & Creative \\
\hline Exemplar paper & Teece et al. (1997) & $\begin{array}{l}\text { Eisenhardt and Martin } \\
\qquad(2000)\end{array}$ & \\
\hline Key concerns & $\begin{array}{c}\text { Optimality } \\
\text { Problem-solving }\end{array}$ & Sustainability & Creativity \\
\hline Focal Units & Corporation & Organization & Situation \\
\hline Key process & Control & Co-ordination & Negotiation \\
\hline Process style & Scientific-logical & Cultural-cohesive & Political- interactive \\
\hline Strategic behavior & $\begin{array}{c}\text { Choice - } \\
\text { decision-making }\end{array}$ & $\begin{array}{c}\text { Output } \\
\text { performance }\end{array}$ & $\begin{array}{c}\text { Outcome } \\
\text { patterns }\end{array}$ \\
\hline Key concepts & Ends, means and & Norms, rules, routines, & Interaction, emergence, \\
\hline
\end{tabular}




\begin{tabular}{|c|c|c|c|}
\hline & conditions & structures & power \\
\hline Key influences & $\begin{array}{c}\text { Economics, natural } \\
\text { sciences }\end{array}$ & $\begin{array}{c}\text { Anthropology, cognitive } \\
\text { psychology }\end{array}$ & $\begin{array}{c}\text { Politics, sociology, social } \\
\text { psychology }\end{array}$ \\
\hline Impact on DC literature & $\begin{array}{l}\text { Firm as a rational actor } \\
\text { seeking to maximize } \\
\text { competitive advantage; } \\
\text { strategy as a cohesive } \\
\text { logical framework and } \\
\text { systematic mechanical } \\
\text { process; DCs as } \\
\text { cognitively driven: } \\
\text { sense, seize, reconfigure }\end{array}$ & $\begin{array}{l}\text { Routines as the basis of } \\
\text { dynamic capabilities; } \\
\text { strategic behavior as } \\
\text { repeated patterning of } \\
\text { resources and activities } \\
\text { geared towards } \\
\text { sustainability }\end{array}$ & $\begin{array}{l}\text { Strategists as creative, } \\
\text { politically oriented actors } \\
\text { enmeshed in dynamic co- } \\
\text { evolving networks of } \\
\text { learning, identity formation } \\
\text { and meaning-making through } \\
\text { situated acts of accepted } \\
\text { practice and improvisation }\end{array}$ \\
\hline
\end{tabular}

Table 1: Concepts of action in the strategy literature

\section{Bibliography}

Adner R and Helfat CE. (2003) Corporate effects and dynamic managerial capabilities. Strategic Management Journal, 24(10) 1011-1025

Allison G. 1998. Conceptual models and decision making. In Strategy Process Content, Context, de Wit B and Meyer R (eds). International Thompson Business Press: London.

Andrews K. 1971. The Concept of Corporate Strategy. Dow Jones Irwin: Homewood, IL.

Augier M, Teece DJ. 2009. Dynamic capabilities and the role of managers in business strategy and economic performance. Organization Science 20(2): 410-421.

Bain J. 1956. Barriers in New Competition: Their Character and Consequences in Manufacturing Industries. Harvard University Press: Cambridge, MA.

Baert P. 1998. Social Theory in the $20^{\text {th }}$ Century. New York University Press: New York. 
Barney J. 1991. Firm resources and sustained competitive advantage. Journal of Management 17: 99-120.

Barney J, Ketchen DJ Jr., Wright M. 2011. The future of resource-based theory: revitalisation or decline. Journal of Management, 37(5): 1299-1315

Barreto I. 2010. Dynamic capabilities: a review of past research and an agenda for the future. Journal of Management 36(1): 256-280.

Beech, N. \& Johnson, P. 2005. Discourses of disrupted identities in the practice of strategic change: The mayor, the street-fighter and the insider-out. Journal of Organizational Change Management, 18(1): 31-47.

Bettis RA, Prahalad CK. 1995. The dominant logic: retrospective and extension. Strategic Management Journal 16(1): 5-14.

Bogner WC, Thomas H, McGee J. 1999. Competence and competitive advantage: towards a dynamic model. British Journal of Management 10(4): 275-290.

Chandler AD Jr. 1962. Strategy and Structure: Chapter in the History of the Industrial Enterprise. MIT Press: Cambridge, MA.

Cyert RM, March JG. 1963. A Behavioural Theory of the Firm. Prentice Hall: Englewood Cliffs, NJ.

Danneels E. 2010. Trying to become a different type of company: dynamic capability at Smith Corona. Strategic Management Journal 32(1): 1-31.

de Wit B, Meyer R. 1998. Strategy Process Content, Context. International Thompson Business Press: London.

Di Stefano G, Peteraf M, Verona G. 2010. Dynamic capabilities deconstructed: a bibliographic investigation into the origins, development, and future directions of the research domain. Industrial and Corporate Change 19(4): 1187-1204.

Easterby-Smith M, Lyles MA, Peteraf MA. 2009. Dynamic capabilities: current debates and future directions. British Journal of Management 20(s1): S1-S8.

Eisenhardt KM, Martin A. 2000. Dynamic capabilities: what are they? Strategic Management Journal 21(10-11): 1105-1121.

Finkelstein S. and Peteraf MA. 2007. Managerial activities: a missing link in managerial discretion theory Strategic Organization 5; 237-248 
Foss N. 2011. Microfoundations for the resource based view. Journal of Management http://jom.sagepub.com/content/early/2011/03/10/0149206310391805

Gavetti G. 2005. Cognition and hierarchy: rethinking the microfoundation of capabilities' development. Organization Science 16: 599-617.

Gavetti G., Rivkin JW. 2007. On the origin of strategy: action and cognition over time. Organization Science 18: 420-439.

Granovetter M. 1985. Economic action and social structure: the problem with embeddedness. American Journal of Sociology 91: 481-510.

Greenwood R, Suddaby R, Hinings CR. 2002. Understanding radical organizational change: bringing together the old and the new institutionalism. Academy of Management Journal 45(1): 58-80.

Hamel GL, Prahalad CK. 1989. Strategic intent. Harvard Business Review, May-June Issue: 63-76.

Hassard J, Holliday R, Willmott H (eds). 2000. Body and Organization. Sage: London.

Helfat CE. 2000. Introduction [by the guest editor]. Strategic Management Journal, Special Issue [on the evolution of firm capabilities] 21 (10-11): 955-960.

Helfat CE., Finkelstein, S., Mitchell W., Peteraf MA., Singh H., Teece DJ, and Winter S. (2007) Dynamic Capabilities: Understanding Strategic Change in Organizations. Malden, Blackwell

Helfat CE, Peteraf MA. 2003. The dynamic resource-based view: capability lifecycles. Strategic Management Journal 24(10): 997-1010.

Helfat C E and Peteraf, M A (2009) Understanding dynamic capabilitys: progress along a development path, Strateegic Organization, 7(1), 91-102

Hendry J. 2000. Strategic Decision Making, discourse and strategy as social practice. Journal of Management Studies 37: 955-977

Joas H. 1996. The Creativity of Action. Polity Press: Cambridge, UK.

Johnson G, Langley A, Melin L, Whittington R. 2007. Strategy as Practice: Research Directions and Resources. University Press Cambridge: Cambridge.

Laamanen T, Wallin J. 2009. Cognitive dynamics of capability development paths. Journal of Management Studies 46(6) 950-981. 
Lyles MA and Mitroff I. (1980) Organizational Problem Formulation: An Empirical Study. Administrative Science Quarterly 25 102-115

MacIntosh R, MacLean D. 1999. Conditioned emergence: a dissipative structures approach to transformation. Strategic Management Journal 20: 297-316.

MacLean D, MacIntosh R, Grant S. 2002. Mode 2 management research. British Journal of Management 13(3): 189-207.

Makadok R. 2001. Toward a synthesis of the resource-based and dynamic-capability views of rent creation. Strategic Management Journal 22(5): 387-401.

March JG. 1994. A Primer on Decision Making: How Decisions Happen. The Free Press: New York.

Martin JA. 2011. Dynamic managerial capabilities and the multibusiness team: the role of episodic teams in managerial leadership groups. Organization Science 22(1): 118-140.

Mason R, Mitroff I. 1981. Challenging Strategic Planning Assumptions. Wiley and Sons: New York and Chichester.

Mayer M, Whittington R. 1999. Strategy, structure and systemness: national institutions and corporate change in France, Germany and the UK, 1950-1993. Organization Studies 20(6): 933-959.

Miner AS. 1994. Seeking adaptive advantage: evolutionary theory and managerial action. In Evolutionary Dynamics of Organizations, Baum, JAC, Singh JV (eds). Oxford University Press: New York; 76-89.

Mintzberg H. 1978. Patterns in strategy formulation. Management Science 24(9): 934-948.

Nelson RR, Winter SG. 1982. An Evolutionary Theory Of Economic Change. Belknap Press: Cambridge, MA.

Oliver C, Holzinger I. 2008. The effectiveness of strategic political management: a dynamic capabilities framework. Academy of Management Review 33(2): 496-520.

Pavlou and el Sawy, 2011 Understanding the Elusive Black Box of Dynamic Capabilities., Decision Sciences 42 (1): 239-273

Peteraf MA, Pitelis CN, Zollo M. 2008. On the metamorphosis of (the theory of) the firm: an introduction. Organization Studies 29(8 \& 9): 1109-1115.

Pettigrew AM. 1973 Politics of Organizational Decision Making. Tavistock, London 
Pettigrew, AM. 1992. The Character and Significance of Strategy Process Research. Strategic Management Journal, 13 (s):5-16

Porter ME. 1980. Competitive Strategy. The Free Press: New York.

Porter ME. 1985. Competitive Advantage - Creating and Sustaining Superior Performance. The Free Press: New York.

Prahalad CK, Hamel G. 1990. The core competence of the corporation. Harvard Business Review, May/June Issue: 79-93.

Priem RL, Butler JE. 2001a. Is the resource-based theory a useful perspective for strategic management research? Academy of Management Review 26(1): 22-40.

Priem RL, Butler JE. 2001b. Tautology in the resource-based view and implications of externally determined resource value: further comments. Academy of Management Review 26(1): 57-66.

Reays T. and Hinings CR. 2009. Managing the Rivalry of Competing Institutional Logics, Organization Studies 30(06): 629-652

Regnér P. 2008. Strategy-as-practice and dynamic capabilities: steps towards a dynamic view of strategy. Human Relations 61(4): 565-588.

Rouleau, L. 2003. 'Micro-strategy as gendered practice: Resisting strategic change through the family metaphor', Paper presented at the 19th EGOS Colloquium, Copenhagen.

Rumelt RP. 1984. Towards a strategic theory of the firm. In Competitive Strategic Management, Lamb RB (ed). Prentice Hall: Englewood Cliffs, NJ; 556-570.

Salvato C. 2009. Capabilities unveiled: the role of ordinary activities in the evolution of product development processes. Organization Science 20(2) 384-409.

Schein EH. 1985. Organizational Culture and Leadership. Jossey-Bass: San Francisco.

Schendel D. 1992. Introduction. Strategic Management Journal, Winter Special Issue [on fundamental themes in strategy process research] 13(s): 1-3.

Schumpeter J. 1943. Capitalism, Socialism and Democracy. Unwin University Books: London.

Scott RW. 1985. Institutions and Organizations. Sage: London.

Senge P. 1990. The Fifth Discipline: the Art and Practice of the Learning Organization. Currency/Doubleday: New York. 
Spender JC. 1989. Industry Recipes - An enquiry into the Nature and Sources of Managerial Judgement. Basil Blackwell: New York.

Spender JC, Grant RM. 1996. Knowledge and the firm: overview. Strategic Management Journal, Winter Special Issue 17: 5-9.

Teece DJ, Pisano G, Shuen A. 1997. Dynamic capabilities and strategic management. Strategic Management Journal 18(7): 509-533.

Teece DJ. 2007. Explicating dynamic capabilities: the nature and microfoundations of (sustainable) enterprise performance. Strategic Management Journal 28(13): 1319-135

Thietart RA, Forgues B. 1997. Action, structure and chaos. Organizational Studies 18(1): 119-143.

Tsoukas H. 1996. The firm as a distributed knowledge system: a constructionist approach. Strategic Management Journal, Winter Special Issue 17: 11-25.

Tsoukas H, Knudsen C. 2003. Introduction: The need for meta-theoretical reflection in Organization Theory. In The Oxford Handbook of Organization Theory, Tsoukas H, Knudsen, C (eds). Oxford University Press: Oxford; 1-36.

Tushman M, Romanelli E. 1985. Organizational evolution: a metamorphosis model of convergence and reorientation. In Research in Organizational Behavior, Cummings LL, Staw B (eds). JAI Press: Greenwich, CN; 172-222.

Wang CL, Ahmed PK. 2007. Dynamic capabilities: a review and research agenda. International Journal of Management Reviews 9(1): 31-51.

Weber M .1978. Economy and Society. University of California Press: Berkeley.

Wernerfelt B. 1984. A resource-based view of the firm. Strategic Management Journal 5: $171-181$.

Wenger E. 1998. Communities of Practice: Learning, Meaning and Identity. Cambridge University Press: Cambridge.

Whittington R. 1992. Putting Giddens into action: social systems and management agency. Journal of Management Studies 29(6): 693-712.

Whittington R. 2003. The work of strategizing and organizing: for a practice perspective. Strategic Organization 1: 119-127. 
Whittington R. 2006. Completing the practice turn in strategy research. Organization Studies 26(4): 613-634.

Williamson, O. E. 1991. Strategizing, economizing, and economic organization. Strategic Management Journal, 12(S2), 75-94.

Winter SG. 2003. Understanding dynamic capabilities. Strategic Management Journal 24(10): 991-995.

Zahra SA, Sapienza HJ, Davidsson P. 2006. Entrepreneurship and dynamic capabilities: a review, model and research agenda. Journal of Management Studies. 43(4): 917-955. 